\title{
NO TABULEIRO PESSOANO
}

\author{
Maria Helena Nery Garcez'
}

Recebido: 01/06/2015

Aprovado: 30/06/2015

RESUMO: O texto analisa as relações estabelecidas entre os heterônimos das Ficções do interlúdio no tabuleiro pessoano e tira conclusões sobre sua liberdade e pessoalidade. Analisa também outro jogador dentro do tabuleiro, embora fora das Fiçcoess, o ortônimo, dando ênfase especial a poemas, muitos deles só publicados a partir das edições críticas e nas completas. Das análises realizadas, concluo que o ethos do ortônimo precisa ser revisto e completado e qual é o maior valor que preside à obra pessoana.

PALAVRAS-CHAVE: Ortônimo: revisão de seu ethos; Heterônimos: relações intratextuais; Fernando Pessoa e a liberdade; Fernando Pessoa e a pessoalidade.

\section{ON PESSOA'S GAME BOARD}

ABSTRACT: This paper analyzes the relations between the heteronymous of Ficcōes do interlídio in Pessoa's board game and draws conclusions about their freedom and personhood. It also analyzes another player within the board, though out of the Fições, the orthonymous, with special emphasis on poems, many of them published only from the critical editions and in complete editions. The analyses conclude that the ethos of orthonymous needs to be reviewed and completed and which is the highest value that presides Pessoa's work.

KEYWORDS: Orthonymous: review of his ethos; Heteronymous: intratextual relations; Fernando Pessoa and freedom; Fernando Pessoa and personhood.

É uma honra estar a falar na abertura da Seção Brasileira do Congresso Internacional 100 Orpheu. Agradeço à organização o convite que me fez e tenho consciência de que outros colegas, de tradição pessoana, poderiam estar aqui, em meu lugar. Como não lembrar os nomes de Massaud Moisés, Carlos Felipe Moisés, Álvaro Cardoso Gomes, Leyla Perrone Moisés, plêiade de estudiosos que fizeram avançar o conhecimento do poeta de Orpheu? Caiu-me, contudo, em sorte a incumbência e, feita essa singela evocação dos companheiros da minha geração, aos quais homenageio, sem esquecer Duílio Colombini, não mais entre nós, passo a dividir com os que me ouvem algumas reflexões.

Ao considerar o que gostaria de transmitir à comunidade brasileira, decidi tratar do que me pareceu mais novo depois da ocorrência das edições críticas e/ou das completas, aparecidas a partir dos finais dos anos 80 e durante as décadas de 90 e 2000. No Brasil, uma editora publicou várias dessas edições completas, facilitando entre nós o acesso a uma visão mais íntegra da obra

\footnotetext{
${ }^{1}$ Professora Sênior do Programa de Pós-graduação de Literatura Portuguesa da FFLCH da Universidade de São Paulo.
} 
pessoana, embora as organizadoras dos alentados livros da poesia ortônima ${ }^{2}$ tenham alertado, no Posfácio do volume publicado em 2009, para que nem mesmo com a leitura daquele vasto corpus o leitor teria a visão total dessa faceta pessoana e esmiuçaram as razões que a essa afirmação. Remeto os interessados à leitura do Posfácio.

Apesar das razões que permitem compreender não estarmos diante de publicações indiscutíveis, indubitavelmente, entretanto, podemos ter agora uma visão da obra de Pessoa bem mais diversificada e rica do que a que tínhamos antes. ${ }^{3} \mathrm{Na}$ minha leitura, as maiores surpresas me foram reservadas pela poesia ortônima, a que darei importância maior nesta fala, não sem antes fazer uma recapitulação de minha trajetória crítica pessoana, necessária para melhor compreensão das conclusões a que pretendo chegar.

Sobre o poeta de Orpheu, meu primeiro grande trabalho surgiu quando, em 1977, ao ministrar um curso de graduação sobre Alberto Caeiro, imediatamente após ler o $1^{\circ}$ verso de um poema, pensei: mas isso é o "Cântico do Sol” de São Francisco de Assis às avessas. Na aula daquela noite, comentei-o com os alunos e não fui além. Quase um ano depois me ocorreu escrever um artigo desenvolvendo esse spunto, para um jornal no qual colaborava às vezes. Em seguida perguntei-me se não haveria nos poemas Alberto Caeiro mais elementos a aprofundar. Os pensamentos, então, se atropelaram: e se essa paródia do Cântico pudesse proporcionar matéria para minha tese de livre-docência? Reli os poemas Caeiro e descobri que a paródia não se limitava àquele texto exemplar, mas que neles havia uma retomada de expressões linguísticas características do linguajar franciscano e da linguagem de prece cristã, sutilmente empregadas em oposição ao sentido com que apareciam nos textos-modelos, o que, de fato, caracterizava uma paródia.

Solicitei, então, à Fundação Calouste Gulbenkian e recebi uma bolsa de três meses para investigar se havia presença de Francisco de Assis entre o que restava da biblioteca de Pessoa, em casa de sua irmã, em Lisboa, e para lá consultar os documentos de seu espólio na Biblioteca Nacional. Passados mês e meio de decifração de manuscritos e pesquisa, encontrei pela $1^{\text {a }}$ vez,

${ }^{2}$ Cf. PESSOA, Fernando. Poesia (1931-1935 e não datada). Edição: Manuela Parreira da Silva, Ana Maria Freitas, Madalena Dine. São Paulo, Companhia das Letras, 2009. p. 617.

${ }^{3}$ Menciono, como exemplo, o caso das grandes odes de Álvaro de Campos, que as edições tradicionais, da Ática e da Aguilar, nos haviam transmitido. Com exceção da "Ode Triunfal" e da "Ode Marítima", publicadas, pelo próprio Fernando Pessoa no $1^{\circ}$ e no $2^{\circ}$ número, respectivamente, da Revista Orpheu, em 1915, todas sofreram importantes modificações e não são mais aqueles poemas com os quais durante anos convivemos, enquanto um tradicional poema, tido como do engenheiro modernista, "A casa branca nau preta", deixou de fazer parte do conjunto Campos e entrou a fazer parte dos poemas ortônimos. 
uma explícita referência a São Francisco de Assis ligado a Caeiro. Depois de examinados mais de 2.000 documentos (e não percorri todo o espólio), encontrei, ao final, sete referências a Francisco de Assis relacionadas a Alberto Caeiro. A título de exemplo, cito dois documentos, àquela altura inéditos:

- documento 12116 (Verso): "Caeiro é o S. Francisco de Assis do novo paganismo". Trata-se de um juízo de António Mora.

- documento 14 B-6 a (continuação), em inglês, envelope Apreciações Literárias em que Pessoa confronta Whitman e Caeiro: W. rarely has the tender emotion that is constant characteristic of C. C. is an atheist St.Francis of Assisis. Whit. can neither be called an atheist nor a S. Francisco de Assis." (apud GARCEZ, 1985, p. 57, 61)

Realizei, a seguir, uma análise do "Cântico do Sol", paradigma de visão cristã da Natureza, que não a via só em si mesma, mas também como criação divina, dela patenteando simultaneamente uma visão imanente e transcendente. A essa visão, Alberto Caeiro - Mestre dentro das Fiçcões do Interlúdio - eliminando a visão transcendente, opunha outra, só imanente; este era o cerne da Nova Revelação, o Novo Paganismo que anunciava. Dentro da tradição dos poetas da Natureza, o "Cântico do Sol” celebrava uma visão cristã; os poemas Caeiro visavam árdua e polemicamente reconstruir uma visão pagã já presente na Antiguidade em Lucrécio e criar nova visão pagã, incorporando dados do sensualismo filosófico moderno.

Para o poema de Francisco de Assis usei o termo "celebrar", pois embora em estilo humilde, o Cântico exulta de entusiasmo e alegria. Quanto aos poemas Caeiro, usei o verbo “construir", modalizado pelos advérbios “árdua" e "polemicamente”, porque, não obstante seu elevado valor estético, essa construção, que é obra persuasória, debate-se acerbamente para se manter em pé, sendo continuamente acusada de contradições pelos seus leitores insipientes com s e com c. Seduzidos por ela, geração após geração, seus leitores amam-na, acusando-a de contraditória. E a contradição maior que surpreendi, através da análise das estruturas linguísticas dos poemas, foi mostrar que muitas delas e dos procedimentos que Caeiro empregava não eram alheios aos que podíamos encontrar na linguagem por ele criticada em Francisco de Assis ou nas formulações cristãs. No final das contas, a mundividência imanente e não cristã, que tão sistematicamente procurara professar e transmitir, resultou surpreendente: Francisco, quase um puro intuitivo, fazia pensar no homem primevo, anterior à queda; Alberto Caeiro, intuitivo pelo discurso da razão, fazia pensar no homem "doente" e chegou a resultado oposto àquele a que se

\footnotetext{
${ }^{4}$ apud GARCEZ, Maria Helena Nery. Alberto Caeiro/ "Descobridor da Natureza"? Porto: Centro de Estudos Pessoanos, 1985, p. 57, 61.
} 
propôs: ele que se queria um arquétipo do intuir acabou sendo um arquétipo do pensar. Sua linguagem revelava manter muitas vezes uma visão hierárquica e organológica da Natureza, mais própria da tradição que pretendia destruir e frontalmente contrária a seu projeto pagão, fazendo uso de metáforas, alegorias e antropomorfizações, isto é, do pensamento analógico. Por essas e outras razões, pus em questão a afirmação que o heterônimo fez de si no poema XLVI do Guardador de Rebanhos, no livro: Alberto Caeiro/ "Descobridor da Natureza"?, publicado no Porto pelo Centro de Estudos Pessoanos, em 1985.

Prosseguindo pelas trilhas pessoanas, acompanhei o Mestre nas suas relações intratextuais com os discípulos. Enquanto guia espiritual, ele ouve confidências tanto de Ricardo Reis (“Mestre, são plácidas/ Todas as horas...") ${ }^{5}$, quanto de Álvaro de Campos ("Mestre, meu mestre querido" $)^{6}$.

Se para Caeiro o melhor lugar onde as flores estão e devem estar é em a Natureza, nos campos, nas árvores, e, no poema XXXIII de O Guardador de Rebanhos, diz ter pena "das flores nos canteiros dos jardins regulares" (PESSOA, 2007, p. 64) ${ }^{7}$, bem como no III, vê como triste o gesto de Cesário Verde de “esmagar flores em livros/ E pôr plantas em jarros...." (PESSOA, 2007, p. 64) ${ }^{8}$, a confidência de Reis ao Mestre se abre dizendo da placidez de todas as horas que perdemos “Se no perdel-as,/Qual n’uma jarra,/Nós pomos flores”. Não repugna ao discípulo Reis cortar as flores de seu habitat natural e pô-las numa "jarra". Como o Mestre, ele ama a Natureza, as flores, mas diferentemente dele, colhe-as e não considera triste servir-se delas para embelezar um ambiente, usa-las para uma finalidade estética, gesto que Caeiro absolutamente não faz. Este, ao olhar a Natureza, nunca está preocupado com o passar do tempo e a perda das horas e da vida, não está pensando nisso; está simplesmente a gozá-la. Ricardo Reis, pelo contrário, ouve continuamente uma música de fundo: a do fluir do tempo, motu perpetuo qual curso de um rio, que ele só consegue exorcizar criando alguma modalidade de beleza ou fruindo de um jogo.

\footnotetext{
${ }_{5}^{5}$ PESSOA, Fernando. Poemas de Ricardo Reis. Vol. III. Edição de Luiz Fagundes Duarte Lisboa: Imprensa Nacional - Casa da Moeda, 1994. p. 87.

${ }^{6}$ PESSOA, Fernando. Álvaro de Campos. Livro de Versos. Introdução, transcrição, organização e notas: Teresa Rita Lopes. $1^{\text {a }}$ ed. Lisboa: Lello \& Irmão, 1993. p. 246.

${ }^{7}$ PESSOA, Fernando. Poemas completos de Alberto Caeiro. Introdução, comentários e notas Maria Helena Nery Garcez. São Paulo: Companhia Editora Nacional: Editora Lazuli, 2007. p. 64.

${ }^{8}$ Idem, ibidem, p. 64.
} 
Dessa constatação surgiu o livro O tabuleiro antigo. Uma leitura do heterônimo Ricardo Reis, em 1990, obra em que se vê Pessoa debruçando-se preferencialmente sobre os valores, como se depreende do estudo de sua linguagem. Dela recapitulo apenas que, numa casa, o pôr flores numa jarra visa eleva-la a uma ordem mais alta, a estética. Realizar um gesto estético é algo de que o homem é capaz, um animal, não. A arte vai além da mera satisfação de uma necessidade material e o eleva a uma ordem superior que o torna capaz da beleza com minúscula e de suspeitar, ou ao menos vislumbrar a Beleza com maiúscula.

Poderíamos, então, dizer que Ricardo Reis é discípulo do Mestre? Em sua confidência, na ode em questão, ele aparentemente o é, quando afirma que devemos decorrer a vida "tranquilos, plácidos/ Tendo as creanças/ Por nossas mestras,/ E os olhos cheios / De Natureza...”. Da leitura do conjunto de suas odes, porém, concluo que não basta grafar Natureza com maiúscula para ter os olhos cheios de Natureza e nem afirmar que se deve decorrer a vida com tranquilidade e placidez, quando a maior parte das odes fala do medo da morte e da melancolia, quando se busca tão intensamente a arte e o ludo para exorcizar tais terrores. E onde estão suas crianças? Há uma ode em que elas brincam de roda ("O rythmo antigo que há em pés descalços" $)^{10}$, contrabalançando o movimento cíclico da maré que, ao avançar inexoravelmente, escurece a areia, numa sombria sugestão da passagem do tempo, do ritmo da natureza, da presença da morte. Contudo, as crianças brincando de roda realizam um círculo, símbolo de infinito e de perfeição, que se opõe ao movimento cíclico da maré. Esse jogo infantil não constitui uma espécie de imemorial rito de afirmação do espírito em oposição ao determinismo do fenômeno natural? Não se vislumbra aí uma sugestão, ou, pelo menos, uma inconsciente e profunda nostalgia de saída?

O que não teríamos então de afirmar relativamente à ode "Os Jogadores de Xadrez"? $\mathrm{Na}$ situação-limite proposta naquela ode triunfal, assistimos a um ato de liberdade tão extraordinário que a torna escandalosa e chocante. Nela se trata de um ato de escolha libérrima de dois jogadores, que preferem continuar a jogar sua partida de xadrez a reagirem ao se verem vítimas do assalto de guerreiros que estão destruindo sua Cidade, matando seus familiares e que, em breve, também os matarão. Várias vezes, em suas odes, Reis nos diz que só temos a ilusão da liberdade, mas nesta, ele, por antonomásia, celebra um chocante gesto de liberdade. E o

\footnotetext{
${ }^{9}$ GARCEZ, Maria Helena Nery. O tabuleiro antigo. Uma leitura do heterônimo Ricardo Reis. São Paulo: Edusp, 1990.

${ }^{10}$ PESSOA, Fernando. Poemas de Ricardo Reis. Vol. III. Edição de Luiz Fagundes Duarte. Lisboa: Imprensa Nacional - Casa da Moeda, 1994. p. 67.
} 
mesmo não acontece na antológica ode do convite e desconvite ao amor que Reis faz a Lídia, à beira-rio? Não são Reis e Lídia livres para não viver o "carpe diem” porque podem abster-se e acham que isso "mais vale" do que ceder ao impulso da natureza? Trata-se de outra escandalosa afirmação de liberdade e da ordem espiritual. A melancolia do mundo antigo, contudo, pesa sobre Ricardo Reis, cujo valor maior não é a Natureza, mas são o jogo e o belo, que trazem consigo a abertura para a liberdade e o vislumbre da transcendência.

E Álvaro de Campos? Como é seu status enquanto discípulo do Mestre? Parece interessante partir igualmente de sua confidência ao Mestre, por ocasião do poema, de 15/4/1928, do qual transcrevo os versos:

"Meu mestre e meu guia!/ A quem nenhuma coisa feriu, nem doeu, nem perturbou,/Seguro como um sol (...),/ Natural como um dia (...),/ Meu mestre, meu coração não aprendeu a tua serenidade./ Meu coração não aprendeu nada./ Meu coração não é nada,/ Meu coração está perdido.// Mestre, só seria como tu se tivesse sido tu." (PESSOA, 1993, p. 246) ${ }^{11}$

Embora nesse poema Campos nomeie Alberto Caeiro como "Mestre e guia", ele não deixa de confrontar-se com ele e, com clareza, de mostrar-lhe suas diferenças, de como a relação Mestre-discípulo foi frustrada. Tudo se resume no verso de magistral afirmação de pessoalidade: "só seria como tu se tivesse sido tu". É ele, o assim chamado discípulo, quem, afinal, acaba dando lição ao Mestre: um outro eu (mesmo se heterônimo) é singular; ele, Álvaro de Campos, é uma "pessoa" com sua singularidade e não poderia ser como Alberto Caeiro. Da relação entre o "Mestre" e seus dois "discípulos" aprende-se, portanto, pessoalidade, a singularidade das pessoas.

Numa comunicação enviada ao II Congresso de Estudos Pessoanos de Nashville, 1983, e publicada nas $A c t a s^{12}$, leio Campos sob o enfoque ascético-místico. Ao fazê-lo, tomo como ponto de partida a tópica situação, em seus poemas, do confronto entre dois tempos, o outrora e o agora, a da torturada consciência de uma defasagem entre o eu primitivo e o atual. Se esse eu primitivo é, nalguns poemas, identificado ao da infância, como em "Aniversário", ao leitor atento não escapa que esse eu vai assumindo uma dimensão muito mais abrangente, ganhando significação originária, anterior mesmo ao seu ingresso na dimensão temporal. Auxiliar-nos-á a compreender isso melhor se recorrermos ao poema "Pecado Original", no qual ele se volta para

${ }^{11}$ PESSOA, Fernando. Álvaro de Campos. Livro de Versos. Introdução, transcrição, organização e notas: Teresa Rita Lopes. $1^{\mathrm{a}}$ ed. Lisboa: Lello \& Irmão, 1993. p. 246.

12 Actas do II Congresso Internacional de Estudos Pessoanos. Porto: Centro de Estudos Pessoanos, 1985, p.181-192. 
essa noção a fim de dizer que, se alguém pudesse escrever a história do que esse pecado poderia ter sido, essa seria a verdadeira história da humanidade. $\mathrm{O}$ eu originário é um eu anterior ao histórico e é desse que, dolorosamente, ele sente nostalgia. ${ }^{13}$

Em "Pecado Original" o eu se autodefine com esta fórmula lapidar: "Sou quem falhei ser" (PESSOA, 1993, p. 321), condição que estende aos demais homens. Daí o mundo the aparecer como uma incompletude ontológica, a exemplo dos versos "este drama sem theatro,/Ou este theatro sem drama” (idem, p. 320), ou “(...) Sou eu mesmo, o trocado,/O emissário sem carta, nem credenciaes, / O palhaço sem riso(...)" (idem, p. 299).

Paralelamente a esta consciência de incompletude, há ânsia de salvação, expectativa de um dia em que ela se consubstancie, como no poema "Magnificat", de 1933, e mesmo num anterior, o que principia com o verso “A liberdade, sim, a liberdade!”, de 1930 e que permaneceu inédito até a edição do Livro de Versos de 1993. Ele tem versos como:

"A liberdade do vagar, do pensamento são, do amor às coisas naturaes/ A liberdade de amar a moral que é preciso dar à vida!/ Como o luar quando as nuvens abrem/ A grande liberdade christã da minha infância que resava/ Extende de repente sobre a terra inteira o seu manto de prata para mim..." (PESSOA, 1993, p. 291).

Três anos após esse poema de apologia da liberdade, cuja estrofe final proclama:

"Ah, tenho uma sede sã. Dêem-me a liberdade,/ Dêem-ma no pucaro velho de ao pé do pote/Da casa do campo da minha velha infancia.../Eu bebia e ele chiava,/ Eu era fresco e ele era fresco,/ E como eu não tinha nada que me ralasse, era livre./ Que é do pucaro e da innocencia?/Que é de quem eu deveria ter sido? / E salvo este desejo de liberdade e de bem e de ar, que é de mim? (idem, p. 291),

encontraremos nova reflexão sobre a liberdade, no poema "Alli não havia electricidade", de 18/12/1934. Neste, que versa sobre a $1^{a}$ Epistola aos Coríntios, lida à luz mortiça de uma vela, numa pousada de província, os versos finais dizem:

"Sou nada.../Sou uma ficção.../Que ando eu a querer de mim ou de tudo neste mundo?/ "Se eu não tivesse a caridade".../ E a soberana voz manda, do alto dos séculos,/ A grande mensagem em que a alma é livre.../“Se eu não

13 Chesterton, em seu livro Ortodoxia, de 1909, apresenta pensamentos análogos a versos de "Pecado Original”. Diz: "Todos lemos em livros científicos e, na verdade, em todos os romances, a história do homem que esqueceu seu nome. Esse homem caminha pelas ruas e pode ver e apreciar tudo; só que não se lembra de quem ele é. Bem, todos os homens são esse sujeito da história. Todos os homens se esqueceram de quem são. Alguém pode entender o cosmos, mas jamais o ego; (...) Todos padecemos sob a mesma calamidade mental; todos nos esquecemos de nosso nome. Todos nos esquecemos do que realmente somos. (... $)^{13}$. Teria Pessoa por acaso lido esta obra de Chesterton? 
tivesse a caridade"... /Meu Deus, e eu que não tenho a caridade!..."( idem, p. 343).

No primeiro poema citado sobre a liberdade, Campos quer a liberdade, cuja água fresca ele bebia na infância, no velho púcaro também fresco e inocente. No $2^{\circ}$ poema, condiciona a recepção da liberdade à posse da caridade, segundo "a grande mensagem” que lê primeiro "à luz de uma vela mortiça” na $1^{a}$ Epistola aos Coríntios, depois relê "à luz de uma vela subitamente antiquíssima,/ E um grande mar de emoção ouviu-se dentro de mim”. Ao relê-la, Campos é subitamente iluminado por essas palavras da Escritura, que lhe revelam a vinculação da liberdade à caridade. Ele é sujeito passivo de uma iluminação, fenômeno místico. Esperaríamos tais vivências religiosas de um discípulo de Caeiro?

$\mathrm{Na}$ comunicação do Congresso de Nashville, eu finalizava tecendo considerações a respeito do poema "Gostava de gostar de gostar" (idem, p. 287), em que se dá uma reveladora pista sobre o não florescimento dessa incipiente veia mística. Campos, ao ouvir numa conversa que "no desenvolvimento da metaphysica/ De Kant a Hegel/ Alguma coisa se perdeu", faz uma associação de ideias. Ele se lembra de uma frase, em latim, de Santo Agostinho, "Nondum amabam et amare amabam", cuja tradução fornece o $1^{\circ}$ verso do poema, "Gostava de gostar de gostar". Ora, Álvaro de Campos gostava/gostaria de gostar de gostar, nostalgia a caridade de que fala Agostinho, mas não consegue crer, talvez porque na sua formação entrou Hegel, e, com este filósofo, perdeu-se o sentido sobrenatural da fé. Se em Kant a fé num Deus transcendente, embora pietista, era irrecusável, em Hegel, a fé incorporou-se à razão, não é mais do que uma função da razão. O desígnio agostiniano nele permaneceu remoto, apenas como nostalgia de seu direcionamento místico falhado.

No tabuleiro pessoano, portanto, Mestre Caeiro, tido como guia espiritual, teve, pois, dois discípulos, que o interpretaram cada um à sua maneira. Esses discípulos conduziram-se segundo a lei da liberdade e seguiram caminhos próprios. Embora num fragmento sem data, não assinado, publicado pela primeira vez como "Nota Preliminar" às Fiçcôes do Interlúdio, da Aguilar, se encontre, em meio a uma extensa frase, a afirmação pessoana "não crendo em nenhum fragmento de liberdade humana" (PESSOA, 1972, p. 197), a relação dos heterônimos entre si patenteia liberdade, o jogo pessoano exibe liberdade, como vimos na mostra das reflexões feitas acerca de Ricardo Reis e de Álvaro de Campos em relação ao Mestre e, individualmente, em cada um deles em suas aspirações e desígnios. 
No tabuleiro pessoano, entre outras, ainda encontramos, fora das Fições do Interlúdio, a figura do ortônimo, que nele também joga sua aliciadora partida. Ele apresentou modalidades que tiveram seguidores, os -ismos do paulismo, interseccionismo e sensacionismo, vanguardas do Orpheu. Em lances magistrais, criou dois poemas ícones de sua obra, o "Autopsicografia", perfeita síntese da criação e recepção da obra de arte em poesia e o "Isto", sutil e irônica exposição de sua própria poética. Esses dois poemas alimentaram décadas de reflexão, análises e críticas, continuam fazendo-o e, acredito, continuarão. Eles não bastavam para inserir Fernando Pessoa no coração da modernidade? E o forte intelectualismo de muitas de suas composições não fez com que na Obra poética da Aguilar o poema "Tão abstracta é a ideia do teu ser" recebesse o título de "Análise", título que desapareceu na edição de 2005 da Companhia das Letras? Em grandes traços, a visão que tradicionalmente tínhamos do ortônimo era: poeta cerebral, despersonalizado, que sentia com a imaginação, esotérico com s; tudo isso o tornou conhecido por quase meio século e em meio mundo. Ora, com a chegada das edições críticas e seguintes, a visão do ortônimo, em meu modo de ver, precisa ser revista, seu ethos completado. No $2^{\circ}$ Seminário Preparatório para o Congresso 100 Orphen - Pessoa e seus Mestres, de outubro de 2013, na Faculdade de Filosofia, Letras e Ciências Humanas, apresentei o texto "Uma noite em Durban/ O vislumbre do outro lado", sobre o poema ortônimo "Un soir à Lima", em que principiei a levantar a questão. Em maio de 2014, no evento Pessoa convida Pessoas, na Universidade de Brasília, dei prosseguimento à questão, com a palestra "Um ortônimo bem temperado" e, na Seção Portuguesa do Congresso Internacional 100 anos Orpheu, avancei mais aspectos do tema na conferência "Uma faceta ortônima non despicienda".

Prossigamos agora com um teste: dar a ler o poema "Un soir à Lima" a um leitor de Pessoa dos anos 70 ou 80, desconhecedor das posteriores edições. Não estranharia ele esse ortônimo que lhe surgiria por diante? Quando li esse poema por primeira vez fez-me repensar no poema "Isto". Não é verdade que, em "Un soir à Lima", o ortônimo representa, de modo saturado de emotividade, uma recordação familiar? Essa rememoração vai num crescendo tal que parece inacreditável que o criador de poemas tão cerebrais como o citado "Análise" possa ter escrito estes versos sobre a figura materna que executava uma peça ao piano:

"E eu que nunca julguei que ela morresse/E me deixasse entregue a quem eu sou!/ Morreu, mas eu sou sempre o seu menino./ Ninguém é homem para a sua mãe!/ $\mathrm{E}$ inda através de lágrimas não falha/A memória que tenho/O recorte perfeito da medalha/Daquele perfeitíssimo perfil./ Chora, ao 
lembrar-te, mãe, romana e já grisalha,/ Meu coração teu e infantil." (PESSOA, 2009, p. 439)14

A afetividade o vai pouco a pouco invadindo e o eu dirige-se repetidas vezes à mãe invocando-a, duplica o chamado seguidamente, chegando, no verso 220, a usar o apelativo íntimo e familiar "mamã". E a poética do distanciamento, como é que fica? Em carta a Casais Monteiro, Pessoa escreveu que em Alberto Caeiro havia atingido sua despersonalização máxima ${ }^{15}$. No poema agora citado, ele não teria chegado a um elevado grau de personalização? E a um grau mínimo de despersonalização?

Há pelo menos mais um aspecto a salientar em "Un soir à Lima”. A rememoração do serão familiar e musical vai se tornando cada vez mais entranhável (estrofe $8^{\mathrm{a}}$ ). Apenas digo que aquela reunião familiar vencia o tempo e foi vivida pelo ortônimo juvenil como experiência de plenitude, harmonia intensa, união afetiva e também de beleza artística pela peça que a mãe executava ao piano, intensificada pela claridade ingente da enluarada noite africana à beira mar, pela manifestação da candura infantil, ternura e paz de um convívio intuído como sagrado. Intitulei a comunicação "Uma noite em Durban/O vislumbre do outro lado" porque compreendi que, enquanto se dava o serão musical, o eu, à janela da sala, vivia a sua pessoal noite de Durban, saiu do tempo e do espaço, de seu eu de "raciocinador subtil" (verso 139), e "exacto" (verso 179), e foi capaz de vivenciar o sagrado, o eterno daquele momento de profunda unidade amorosa. Viveu um momento de suspensão, de comoção absoluta, numa palavra, um êxtase. Essa experiência profunda, única e sublime ficou eternizada nesse poema nuclear que, segundo o eu da enunciação teve como spunto, a audição no radio da peça musical homônima de Félix Godefroid. Nele, o eu procurou eternizar "Essa sala, essa hora/ Toda a família e a paz e a música (...)" e a "mãe" (idem, p. 442) e a beatitude vivenciada.

Se, no poema "Un soir à Lima", inédito até 2005, escrito dois meses e treze dias antes do falecimento de Pessoa, tivemos as surpresas que acabamos de enunciar, o quanto essa surpresa não cresceu quando encontrei, em poemas de datas muito anteriores à dele, elevado número de composições ortônimas em $1^{a}$ pessoa, impregnadas de afetividade, não presentes nas tradicionais publicações das suas poesias anteriores às edições críticas e, em sua maioria, inéditas.

\footnotetext{
${ }^{14}$ PESSOA, Fernando. Poesia (1931-1935 e não datada). Edição: Manuela Parreira da Silva, Ana Maria Freitas, Madalena Dine. São Paulo: Companhia das Letras, 2009. p. 439.

${ }^{15}$ Cf. PESSOA, Fernando. Obras em prosa. Organização, introdução e notas de Cleonice Berardinelli. $2^{a}$ ed., Rio de Janeiro, Nova Aguilar, 1976, p. 94: “...pus no Caeiro todo o meu poder de despersonalização dramática".
} 
Refiro-me, principalmente, às publicadas na edição Poesia $(1902-1917)^{16}$. Para calibrar melhor o ethos do ortônimo parece-me ser de justiça não vê-lo apenas como o "raciocinador exacto", o cerebral, o que sente com a imaginação e não com o coração, mas aquele que fala com o coração, sim, de algumas figuras do contexto familiar e não apenas em datas próximas da sua morte. Verificamos que estão presentes em suas poesias, desde aquela época abrangida pelo volume citado, doravante designado por I, e que reaparecem também em épocas posteriores, abrangidas pelos dois outros volumes, a saber, (1918-1930) e (1931-1935), doravante designados por II e III. Essas figuras são a "ama” (no I, aparece em três poemas; no II, em um) e a "mãe" (no I, aparece em quatro, no II, em um, no III, em quatro). O total é de treze poemas, e o levantamento não foi exaustivo.

Quanto à figura da mãe, nada melhor do que o poema que segue:

Minha mãe, dá-me outra vez

O meu sonho.

Ele era tão belo, mãe,

Que choro porque o tive...

Não era de gente,

Não era de casa,

Não era de andar num lugar,

Não sei de que era ou como era

Mas era tão belo como se eu soubesse agora isso tudo.

Não está à tua direita,

Não está à tua esquerda

E não está no teu colo,

Mas

Era uma uma cousa brilhante

Mas não tinha brilho...

Era uma cousa para criança,

Mas era verdade,

Era um brinquedo

E não acabava,

Era um lugar para ir

Mas a gente não voltava à noite...

Dá-me o meu sonho, mãe,

Assim mesmo como eu não sei o que ele é.

Quero voltar para trás, mãe,

E ir busca-lo ao meio do caminho.

Não sei onde ele está

Mas é ali que está

16 PESSOA, Fernando. Poesia (1902-1917). Edição Manuela Parreira da Silva, Ana Maria Freitas, Madalena Dine. São Paulo: Companhia das Letras, 2006. 


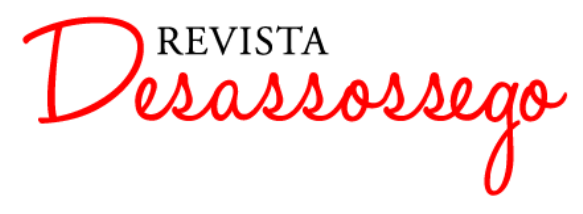

E brilha onde eu o não vejo...

O meu sonho, mãe,

É o meu irmão mais novo ${ }^{17}$.

Eu ando triste, mãe...

Triste como uma ave na gaiola,

$\mathrm{Na}$ gaiola desde inocente...

Dá-me o meu sonho, mãe,

E deixa-me só sonhar...

Não são todos os teus beijos,

Nem todos os teus brinquedos,

Nem o teu colo onde durmo,

Que se parecem com ele

Quando o tenho, tenho-te a ti,

Ainda que lá não estejas, não me faltas lá,

Quando o tenho.

[1916] (não informado se inédito ou não)

( I, p.398)

De 26-7-1910, escolhi para exemplificar a figura da "ama” um singelo poema que mostra bem a afetividade e o quão distante esse ortônimo está "do novelo embrulhado para o lado de dentro”: “Que velho, minha ama,/Que velhinho já.../Faze tu a cama/Que o sono virá.../Faze já a cama.//Que triste, minha ama,/Sempre assim tão triste!/Vê, mesmo na cama ${ }^{18} /$ Esta $^{19}$ dor persiste.../Não durmo, minha ama.” 26-7-1910 (I, p. 105).

Ambos poemas estão construídos numa relação dialógica em que predomina o trato íntimo e afetivo. No primeiro, trata-se de um desejo impossível que o eu ortônimo adulto dirige à mãe, tentando dizer-lhe, como se criança fosse, que ela lhe dê "outra vez" o seu "sonho". Encontra tal dificuldade para explicar-lhe em que esse consiste que diz tudo quanto ele não é, mas não sabe dizer o que ele é. Diante dessa ontologia negativa e dessa fala infantil, num dado momento, $1^{\mathrm{o}}$ verso da $3^{\mathrm{a}}$ estrofe, até repete uma palavra, a modo de quem procura o termo exato e não encontra: "Era uma uma cousa brilhante". Na $6^{a}$ estrofe irrompe a confissão: "Eu ando triste, mãe.../ Triste como uma ave na gaiola, /Na gaiola desde inocente... Dá-me o meu sonho, mãe, / E deixa-me só sonhar...”. Não é algo novo essa face familiar, íntima, sensível e mesmo inofensiva porque infantil, do ortônimo?

\footnotetext{
17 Os dois últimos versos da estrofe estão dubitados.

18 Var. sobrep. para o verso: Até nesta cama.

${ }^{19}$ Var. sobrep. a Esta: Minha.
} 
Outra faceta ortônima que também permaneceu oculta até a eclosão das edições críticas e completas foi a de vários poemas sobre o cristianismo. Neste, de 1-3-1917, cuja primeira publicação foi na edição crítica de João Dionísio, em 2005, aparece cristianismo e referência à mãe:

Entre as tuas joias há um anel antigo,

Com uma gema dos gnósticos, talismã

Nós dissemos à fé da nossa infância: Vai-te.

Esquecemos o que aprendemos com os beijos de mãe.

Hoje não somos felizes, nem grandes, e vem

Sobre nós um tédio

Ó horas sobre os cais dos portos que não veremos!

Vinde um momento fazer parte de um sonho falso.

Quem nos virá dizer as palavras que Cristo

Deixou secretas no fundo divino do seu coração?

Sofrer... Toda a nossa vida dia a dia é isto...

Quem nos consolará, sendo ele a Consolação?...

Mas dos meus sonhos

Só a dor de serem apenas sonhos toca na vida. [1-3-1917]

(I, p.420-421)

Nele o eu, falando em nome de uma geração, relata como se desvencilhou da "fé da [nossa] infância" e, de modo pesaroso, diz terem esquecido o que tinham aprendido "com os beijos de mãe". No hoje do poema, nem ele nem os companheiros de geração são felizes ou bem sucedidos, vivem no tédio e carecem visceralmente das palavras de Cristo e de sua Consolação com maiúscula. É poema típico do ortônimo a que estávamos habituados?

De 1902 a 1935 são numerosos os poemas de problemática cristã dos quais cito os títulos ou primeiros versos apenas dos que estão completos ou com lacunas mínimas. Arrolo: “Ascensão” (1913), "Frei João” (1915), "Senhor, meu passo está no Limiar” (1915), “Quando, cheio do próprio dó" (1928), "Vieram com o ruído e a espada" (1930), "Quanto fui peregrino" (1930), "Cabeça augusta, que uma luz contorna" (1933), "Eu, que vendi a alma a meio diabo" (1934), “A Igreja Católica cobriu como uma redoma" (1934), "O Rei” (1935), "Virgem Maria" (1935), "Mater Desiderata" (sem data). Para que se tenha uma ideia viva do que quis dizer com essa surpreendente presença do cristianismo no ortônimo citarei o poema datado de 10-1-1913, dos 25 anos, intitulado "Ascensão", ainda anterior à eclosão dos dois números de Orpheu e inédito até 2005: 


\section{ASCENSÃO}

Quanto mais desço em mim mais subo em Deus...

Sentei-me ao lar da vida e achei-o frio,

Mas pus tão alta fé nos sonhos meus

Que ardente rio

Do puro Compreender e alto Amor,

Da chama espiritual e interior ${ }^{20}$

Deu nova luz ao meu alheio olhar

$\mathrm{E}$ às minhas faces cor...

E esta fé, esta lívida alegria

Com que, alma de joelhos, ${ }^{21}$ creio e adoro,

É a minha própria sombra que me guia

Para um fim que eu ignoro...

Porque Deus fez de mim o seu altar

Quando Ele me nasceu tal como sou, 22

Se p'ra minha alma volvo um quase-olhar

Não me vejo onde estou.

Eu tenho Deus em mim... Em Deus existo

Quando crê, cega, acha-o minha fé calma...

Maria-Virgem concebeu um ${ }^{23}$ Cristo

Dentro em minha alma...

Alma fria de Altura; que os seus céus

Dentro em si própria acha... Para si morta

Em Deus... Mas o que é Deus? E existe Deus?

Isso que importa?

(I, p. 165)

Como observei alhures, este poema trata do fenômeno da inabitação de Deus na alma do que se exercita na vida de oração e poderia ter sido escrito por um místico cristão, mas, nos dois versos finais, a ascensão anunciada no título conhece uma freada brusca e a dúvida aparece. Na conferência, em Lisboa, discuto este ponto e não a repetirei. Só quis mostrar a profundidade da experiência de cristianismo do ortônimo jovem, desconhecida de seus leitores porque o poema ficou inédito.

Escolhi outro poema, de 28-8-1927. Cito-o, mas não na íntegra:

Não venhas sentar-te à minha frente, nem a meu lado;

Não venhas falar, nem sorrir.

Estou cansado de tudo, estou cansado, E só quero dormir.

Dormir até acordado, sonhando

Ou até sem sonhar,

\footnotetext{
${ }^{20}$ Var.sobrep.para: e interior: - divino amor.

${ }^{21}$ Expressão dubitada: alma de joelhos.

22 Var. na margem para o verso: Sou um sonho de Deus e sei que o sou.

23 Var. sobrep. a um: o.
} 


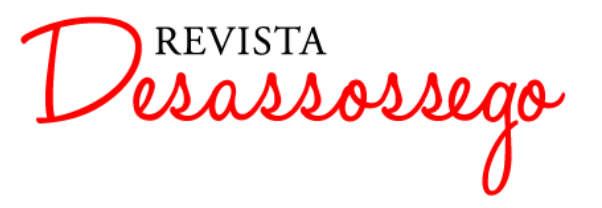

Mas envolto num vago abandono brando

A não ter que pensar.

Nunca soube querer, nunca soube sentir, até

Pensar não foi certo em mim.

Deitei fora entre urtigas o que era a minha fé,

Escrevi numa página em branco, "Fim".

(...)

Acumulei em mim um milhão difuso de vidas,

Mas nunca encontrei parceiro.

(..)

Pus o meu Deus no prego. Embrulhei em papel pardo

As esperanças e as ambições que tive,

E hoje sou apenas um suicídio tardo,

Um desejo de dormir que ainda vive.

(...)

28-8-1927

(II, p. 282-283)

Se tivermos em mente o "Ascensão", escrito 14 anos antes, a mudança de estado de ânimo impressiona. No que acabamos de ler, o eu se encontra exaurido, gasto, desejando a morte, fazendo um balanço negativo de seu percurso existencial. Querer, sentir, pensar, tudo lhe saiu errado e, notavelmente expressiva, é a imagem para explicar o sucedido à fé: "deitei fora entre urtigas o que era a minha fé". A fé, que no poema "Ascensão" fora tratada com vivacidade e alegria, neste, teve destino deplorável e, "numa página em branco", o eu assinou seu "Fim" com maiúscula, por decreto. Mas a constatação não se encerra aí. O eu reforça essa análise que faz de si com o verso desabusado "Pus o meu Deus no prego. Embrulhei em papel pardo/ As esperanças e as ambições que tive”. Pôr seu Deus na casa de penhor, referida como "prego", termo mais baixo, é modo amargo de referir-se ao bota-fora da fé ocorrido em sua vida. Também importa comentar o verso: "Acumulei em mim um milhão difuso de vidas,", que leio como alusivo ao processo de despersonalização, de criação de múltiplos eus, que tiveram como resultado o "nunca encontrei parceiro". Sombriamente, o poema termina com a imagem do naufrágio de uma galera abandonada, à qual ele se identifica.

Se isolada fosse essa visão do processo de despersonalização na poesia ortônima poderia até ser passada por alto. Contudo, ela ocorre mais vezes e, notadamente no poema de 16-3-1934 (III, p. 246), cujo incipit é: "Eu que vendi a alma a meio diabo". ${ }^{24}$

\footnotetext{
${ }^{24}$ Publicado em português na Edição Crítica de 2000, tinha sido publicado em 1998, em tradução francesa, por Patrick Quillier.
} 
Analisei-o em Lisboa. Ressalto apenas que, no dramático balanço de vida feito nas três estrofes principiadas pelo pronome da $1^{\mathrm{a}}$ pessoa, o verso que encabeça a $2^{\mathrm{a}}$ estrofe também se refere ao processo de criação de outros eus em poesia lírica: "Eu, que não sou ninguém de tanto ser". O poeta dramático faz aqui um dramático poema sobre seu processo de criação de "vários poetas escrevendo em poesia lírica", ${ }^{25}$, e o resultado da aventura a que chega é, como no anterior, desejar a morte. Cito ainda uns versos doutro poema de 10-81934: "De tanto me fingir quem sou deveras,/ Já desconheço quem deveras sou." (III, p. 323) ou deste outro, de 24-8-1934, notável balanço de vida:

"E eu, que queria ser só, vejo dançando/Ante meus olhos de quem sou em mim/ Um vil, irrepelível bando/Que não tem nexo mas tem fim.//Não ouso abrir de novo o que fechei./Aqui, escravo dos sonhos que pedi,/Sou verdadeiramente rei,/Ah, mas sou rei de aquilo que perdi.//(...)Porque fechei meu pobre ser comigo?/Porque vendi a natureza a quem/Não tem nem amor nem amigo?/Porque sem paz me tornei eu ninguém?”(III, p. 342).

Encaminhando-nos para a conclusão, lembremos que na "Nota Biográfica de 30 de março de 1935", Pessoa declarou sua posição religiosa como a de um "cristão gnóstico e portanto inteiramente oposto a todas as Igrejas organizadas, e sobretudo à Igreja de Roma" (PESSOA, 1972, p. 199) ${ }^{26}$. Não iremos contraria-lo, mas julgamos importante fazer constar que de 20-4-1934, cerca de um ano antes, data o poema "A Igreja Católica cobriu como uma redoma/Meus dias serenos" ${ }^{27}$, a cuja leitura remeto o publico que me ouve, pois o que ele diz lá é quase inacreditável, não o julgo irônico, e relativiza um pouco a afirmação da referida Nota. Também o analisamos em Lisboa e não repetiremos. Este também só foi publicado por primeira vez na edição crítica de 2000. O que quisemos e queremos mostrar é a forte vertente cristã, no ortônimo, que havia ficado inédita, e que nos seus últimos tempos ele escreveu poemas religiosos, dos quais citaremos dois. Transcrevemo-los.

O primeiro é muito breve, de 21-8-1935, 3 meses e 9 dias antes e sua morte e destaca-se porque é piedoso e se dirige à Virgem Maria. Ei-lo:

VIRGEM MARIA: "Mãe de quem não tem mãe, no teu regaço/Poisa a cabeça a dor universal/E dorme, ébria do fim do seu cansaço.../E tens na mão, usado e nunca imundo,/O pequenino lenço maternal/Com que enxugas as lágrimas do mundo.” (III, p.435-6)

\footnotetext{
${ }^{25}$ Cf. Nota preliminar às "Ficções do Interlúdio", in: PESSOA, Fernando. Obra poética. Organização, introdução e notas de Maria Aliete Galhoz, $4^{a}$ ed. Rio de Janeiro: José Aguilar Editora, 1972. p.199. 26 apud Fernando Pessoa no seu tempo. Lisboa: Secretaria de Estado da Cultura: Biblioteca Nacional, 1988. p.1722.

27 Var. sobrep. a Católica: materna.
} 
O segundo é um soneto de 31-7-1935, 4 meses antes de sua morte. Escolhemos a fixação do texto realizada por Carlos Pitella-Reis, em sua tese de doutoramento:

\section{O REI}

O Rei, cuja coroa de oiro é luz

Fita do alto trono os seus mesquinhos.

Ao meu Rei coroaram-nO de espinhos

E por trono Lhe deram uma cruz.

O olhar fito do Rei a si conduz

Os olhares fitados e vizinhos

Mas mais me fitam, e mortas sem carinhos,

As pálpebras descidas de Jesus.

O Rei fala, e um seu gesto tudo prende,

O som da sua voz tudo transmuda.

E a sua viva majestade esplende;

Meu Rei morto tem mais que majestade:

Fala a Verdade nessa boca muda;

Essas mãos presas são a Liberdade.

(apud PITELLA-LEITA, 2012, p. 239) ${ }^{28}$

O soneto principia em $3^{a}$ pessoa e já no $3^{\circ}$ verso aparece o possessivo "meu" para "Rei": "Ao meu Rei coroaram-no de espinhos". É significativo que o eu da enunciação se reconheça seu súdito. $\mathrm{Na} 2^{\mathrm{a}}$ estrofe a contemplação do Rei se torna mais íntima e ele conta que uma relação especial se estabelece entre ambos: o eu sente-se fitado especialmente. $\mathrm{O}$ Rei constitui um centro catalisador, para Ele converge tudo, e, embora no $2^{\circ}$ terceto se nos fale de sua "boca muda", Ele fala com sua presença, "sua viva majestade esplende". A culminância do soneto está no $2^{\circ}$ terceto, em que a "Verdade", com maiúscula, fala eloquentemente apesar da boca muda, e em que as "mãos presas são a Liberdade", também com maiúscula. Estão presas não porque não houvesse outro jeito, porque o Rei foi apanhado, mas porque Ele se deixou pregar. Aqui se vê a proclamação suprema da Liberdade, do apogeu do ato de Liberdade. Já não se trata de escolher entre jogar o xadrez ou lutar pela vida, ou de viver ou não viver o "carpe diem". Trata-se da Liberdade de Deus, que, sendo

${ }^{28}$ Pequenos infinitos em Pessoa: uma investigaşão filológico-literária pelos sonetos de Fernando Pessoa. Tese de doutorado (importante) defendida e aprovada no Departamento de Letras da Pontifícia Universidade Católica do Rio de Janeiro em 28 de março de 2012. Há variantes significativas deste soneto entre as leituras de Carlos PitellaLeite e a leitura deste mesmo poema, não visto como soneto, pelas editoras da Companhia das Letras. 
Ele mesmo a própria Liberdade, escolhe deixar-se prender por um desígnio mais alto: libertar do mal.

Eis-nos chegados à conclusão.

No tabuleiro pessoano algumas peças são as Ficções do Interlúdio e, na minha visão, de seu jogo resultou liberdade. Vimos a posição pagã de Alberto Caeiro, e como Ricardo Reis e Álvaro de Campos são “discípulos” que não leem pela cartilha do Mestre. Admiram-no, mas seguem caminhos próprios. São livres.

No tabuleiro pessoano, outra peça é o ortônimo, de quem as edições primeiras, ao fazerem uma seleção de poemas, principalmente dos datilografados e praticamente deixando de lado os manuscritos, por serem de mais difícil leitura, transmitiram ao e criaram no público leitor uma imagem incompleta, que as edições críticas e as posteriores vieram completar em pontos importantes, o que procuramos salientar. O ethos do ortônimo foi o que mais nos surpreendeu e permitiu ver um ortônimo não apenas esotérico, mas também cristão, não tão cerebral, mas capaz de sentir não só com a imaginação, mas também e, às vezes, bastante com o coração, não muito convencido dos bons resultados da poética da despersonalização, mas extremamente convencido de que o maior valor, o que cultiva e pratica, o valor que por excelência reconhece, pois que o contempla no próprio Ser divino, é a Liberdade, com maiúscula.

Minha conclusão é: não por acaso um dos últimos poemas do ortônimo é o intitulado "Liberdade", 16-3-1935, em que, com benigna dose de humor, ele conclui sobre Jesus Cristo "que não sabia nada de finanças/Nem consta que tivesse biblioteca..."(III, p. 398). Do tabuleiro pessoano bem como da obra pessoana em geral ressuma liberdade, participação naquela Liberdade que, num de seus últimos poemas, reconheceu como o atributo Divino substantivo.

\section{BIBLIOGRAFIA}

CHESTERTON, G.K. Ortodoxia. Tradução: Almiro Pisetta. São Paulo: Mundo Cristão, 2008 .

GARCEZ, Maria Helena Nery - Alberto Caeiro/ "Descobridor da Natureza"?, Porto: Centro de Estudos Pessoanos, 1985. . "Uma leitura ascético-mística do heterônimo Álvaro de Campos". Actas do II Congresso Internacional de Estudos Pessoanos. Porto: Centro de Estudos Pessoanos, 1985. 
. Trilhas em Fernando Pessoa e Mário de Sá-Carneiro. São Paulo: Edusp: Moraes, 1989.

. O tabuleiro antigo. Uma leitura do heterônimo Ricardo Reis. São Paulo: Edusp, 1990.

PESSOA, Fernando. Poemas completos de Alberto Caeiro. Introdução, comentários e notas de Maria Helena Nery Garcez. São Paulo: Companhia Editora Nacional: Editora Lazuli, 2007. Poesia, 1902-1917. Edição Manuela Parreira da Silva, Ana Maria Freitas, Madalena Dine. São Paulo: Companhia das Letras, 2006.

Poesia, 1918-1930. Edição Manuela Parreira da Silva, Ana Maria Freitas, Madalena Dine. São Paulo: Companhia das Letras, 2007.

Poesia (1931-1935 e não datada). Edição: Manuela Parreira da Silva, Ana Maria

Freitas, Madalena Dine. São Paulo: Companhia das Letras, 2009.

Poemas de Ricardo Reis. Vol.III, Edição de Luiz Fagundes Duarte. Lisboa: Imprensa Nacional - Casa da Moeda, 1994.

Álvaro de Campos. Livro de Versos. Introdução, transcrição, organização e notas:

Teresa Rita Lopes. $1^{\text {a }}$ ed.. Lisboa: Lello \& Irmão, 1993.

Obra poética. Rio de Janeiro, Organização, introdução e notas de Maria Aliete

Galhoz, $4^{a}$ ed. Rio de Janeiro: Aguilar Editora, 1972.

Obras em prosa. Organização, introdução e notas de Cleonice Berardinelli. $2^{\mathrm{a}}$ ed., Rio de Janeiro: Nova Aguilar, 1976.

PEREIRA, Mariella Augusta. A heteronimia: metamorfoses retórico-poéticas. Ethos epathos nas Ficcões do interlúdio. Tese de doutorado defendida e aprovada na Faculdade de Filosofia, Letras e Ciências Humanas da Universidade de São Paulo em 11/07/2014.

PITELLA-LEITE, Carlos. Pequenos infinitos em Pessoa: uma investigação filológico-literária pelos sonetos de Fernando Pessoa. Tese de doutorado defendida e aprovada na Pontifícia Universidade Católica do Rio de Janeiro em 28/03/2012. 